\title{
Income Redistribution and Socio-economic Development ${ }^{1}$
}

\section{Beáta Mikušová Meričkováa ${ }^{2}$, Renáta Halásková ${ }^{3}$}

\begin{abstract}
The trade off efficiency and equity issue, which is represented by income redistribution, becomes increasingly debated not only in economic and social, but also in political dimension. Solution of this trade-off problem is projected into the implementation of social policy and results achieved in macroeconomics policy, with the goal to define the optimal scope and character of the income redistribution processes. The submitted empirical study responds to this problem through the investigation of research question focused on the existence of a relationship between the social protection expenditure (expenditure on policy of family, old age and unemployment) and the achieved level of socio-economic development (quantified by Human Development Index HDI). The existence of this relationship is statistically tested in a sample of 15 countries. The research sample is heterogeneous in relation to the analyzed indicators, and it contains countries with a different level of economics development and income redistribution policy. Based on the results of quantitative analysis in most surveyed countries, impact of social protection expenditure on the reached level of economic development was confirmed. The correlation between the social protection expenditure and socio-economic development is positive in the case of the family and old-age pension policy, and negative in the case of employment policy.
\end{abstract}

Key words: income redistribution, socio-economic development, trade off, Human development index, social protection expenditure

JEL Classification: H5, I38

\section{Introduction}

On average, transfer payments currently comprise a half of all public expenditures in developed countries and their scope is on the increase (Bailey 1995; Cullis, Jones 1987; Hayek 1994; Saunders 1993; Stiglitz 1988). The transfer of means from well-off to

\footnotetext{
${ }^{1}$ The research is supported by the Czech Grant Agency GACR under the contract No. P403/12/0366 Identification and evaluation of region specific factors determining outcomes of reforms based on NPM - the case of CEE.

${ }^{2}$ Matej Bel University in Banská Bystrica, Faculty of Economics, Department of Public Economics and Regional Development, Tajovského 10, 97590 Banská Bystrica, Slovak Republic, e-mail: beata.mikusovamerickova@umb.sk

${ }^{3}$ College of Logistics in Přerov, Department of Economic, Legal and Social Sciences, Palackého 1381/25, 75002 Přerov, Czech Republic, e-mail: renata.halaskova@vslg.cz
} 
socially weak groups of population through public financing is described in the theory of public finances (Apgar, Brown 1987; Bailey 1995; Brown, Jackson 1990; Cullis, Johns 1992; Musgrave 1959; Otáhal, Palát, Wawrosz 2013; Singer 1972; Stiglitz 1988) as redistribution. One of the most discussed matters is that of its need and extent, having not only an economic and social, but also a political dimension.

The goal of this study is to provide empirical view on the trade off efficiency and equity issue in redistribution processes. The theoretical framework of research is based on income redistribution within the neoclassical welfare economy. The analytical part focuses on selected spheres of social policy in relation to human development index, and evaluates development not only as measured by economic advances, but also by improvements in human well-being.

In line with the goal, a subject of research i.e. the mutual relationship of social and macroeconomics policy in the narrower sense is defined. The quantitative research of the existence and character of this relationship assumes a selection of social policy tools quantified through social protection expenditure. We focus on key areas of social policy and monitor the data on social expenditure on family, old age and unemployment.

\section{Theoretical Framework}

Welfare economics represents a neoclassical view on redistribution (Apgar, Brown 1987; Bailey 1995; Brown, Jackson 1990; Cullis Jones 1992; Musgrave, 1959; Singer 1972; Stiglitz 1988). It deals with the function of social welfare, i.e. public interest, and aims to analyze the conditions of its maximizing under specific circumstances, i.e. the amount and quality of production resources available, and demands which are advisable to be satisfied. Public interest is often grasped differently, even contradictorily, which is why its general definition is difficult to provide (Hayek 1994; Nemec, Ochrana, Šumpíková, 2008; Ochrana, Nekola, 2009). Jeremy Bentham, who provided a definition based on the principles of utilitarianism (these were developed further in work by John Stuart Mill and John Austin), was the very first person to set public interest into a wider context and to identify public interest with justice. In 1781, Bentham defined public interest, in other words the interest of a group consisting of individuals, in the introductory part of his paper "Introduction to the Principles of Morals and Legislation" as the sum of individual interests of the individuals ( $\mathrm{W}=\mathrm{U} 1+\mathrm{U} 2+\ldots+\mathrm{Un})$. In order to maximize the sum of individual well-beings, i.e. social welfare (W), the utilitarian theory postulates that redistribution be needed among individuals in such a manner that each individual profited from the income equally. However, this more or less logical utilitarian reason for the need for income redistribution in society to maximize social welfare encounters numerous methodological problems.

In a society, considering a developed society with a large number of members, where individuals may freely use their knowledge and skills to reach their individual usefulness, no public interest controlled by the government can be defined as the sum of the aforementioned individual usefulness, and neither the government nor anyone else is capable of recognizing the circumstances of their achieving. Public interest cannot be a sum of individual needs based on very simple reason: Those defining the rules for public-interest achievement are unable to know the whole host of individual interests, of which the public interest should be, according the utilitarian principles, comprised, nor 
is each individual interest in line with the public one. And it is the aspect of ignorance of all circumstances associated with achieving each individual interest in society that is missing in the utilitarian definition.

Another issue arises during interpersonal comparison of individual usefulness - welfare economics working with the utilitarian concept automatically presupposes higher individual usefulness in individuals with higher income. Nevertheless, is the notion that more money goes hand in hand with higher rate of usefulness, satisfaction and luck adequate?

The stated methodological issues cast doubt on the justification of redistribution from the economic viewpoint (still, from the social perspective, its need is maintained). Also, financial expenses on redistribution processes (Baldock, Mitton, Manning, Vickerstaff 2012; Farnsworth, Irving 2011) raise the issue of the compromise between efficiency and equality, which redistribution represents.

The specific nature of this compromise is described in the relation between social protection and socio-economic development. It is defined by means of statistical testing of mutual dependence of the socio-economic development level (quantified in numerous papers through the Human Development Index - HDI (Costantini, Monni 2008; Diniz, Sequeira 2012) and of the extent of social protection (redistribution in its practical form - (Halásková, Halásková 2013; Immervoll, Richardson 2011; Pestieau 2006).

Many authors consider the Human Development Index (HDI) a more complex indicator of socio-economic development than income per capita, or GDP (Baranová 2013; Costantini, Monni 2008; Ranis 2004). This index combines information on economic growth (GDP per capita in the latest methodology of calculation of national income per capita), level of education (literacy in adult population), and state of health (life expectancy). The economic-development indicator is supplemented with indicators of social development, reflecting on the level of education and providing of health care - Figure 1 (Mankiw 2010, p. 479).

Figure 1 Components of the HDI calculation using the latest methodology

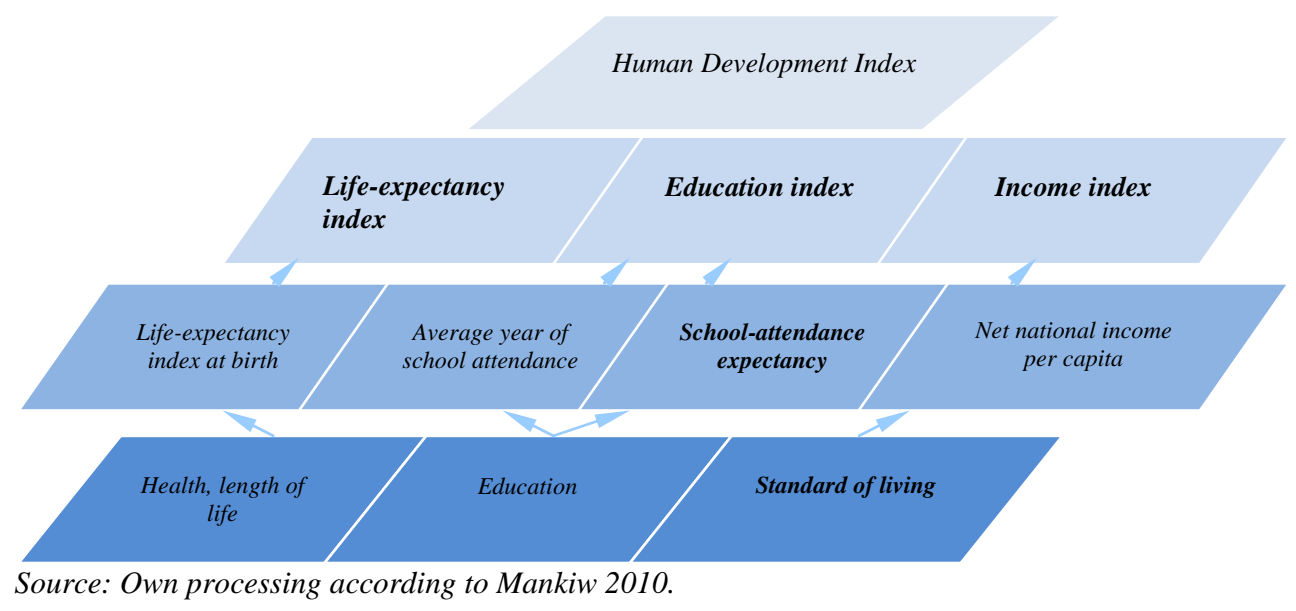


HDI is a geometrical average of partial indexes (LEI: life-expectancy index, EI: education index, GNI: gross national income)

$$
H D I=\sqrt[3]{L E I \times E I \times G N I \text { index }}
$$

Although the HDI is a more complex indicator of economic development when compared to GDP or national income, it must be admitted that even here is room for improvement regarding the complexity of life-quality assessment in specific countries. Diniz, Sequeira (2012) claim that the concept of HDI may not embrace the socioeconomic development exhaustively, as it requires also other important areas, evenly represented and difficult to reach, touching on political, economic, social freedom, or also creativity, productivity and respect towards human rights. The limitations of the HDI are attempted to be eliminated by the Socio-Economic Development Index (SEDI), which, according to Mehrotra, Peltonen (2005), provides four areas in the evaluation: 1) infrastructure (representing the number of transported passengers by air travel, number of kilometres of passengers in rail travel, and the number of phone lines used), 2) the environment (emissions, the volume of GDP gained through recycled energy), 3) education (applications to school with primary and tertiary education) (Hronec, Strangfeldová 2013), 4) state of health of the population (newborn mortality rate, rate of inoculation against three infectious diseases - diphtheria, tetanus and palsy). Compared with the HDI, SEDI omits to take GDP into consideration, which is why it is a more appropriate indicator of economic development on the regional level (Laski, Römisch 2003).

Also other indexes introduce the social dimension into the evaluation of life-quality level: Physical Quality of Life Index, which can be considered a simplified form of the HDI (Costantini, Monni 2008), similarly to the (Human Poverty Index, HPI).

Based on the aforementioned facts, the HDI has been selected for quantification of the economic development.

The data on social protection expenditure and receipts have been calculated in accordance with the methodology of the European System of Integrated Social Protection Statistics (ESSPROS). Social protection encompasses "all interventions from public or private bodies intended to relieve households and individuals of the burden of a defined set of risks or needs, provided that there is neither a simultaneous reciprocal nor an individual arrangement involved"(ESSPROS Manual 2011). Risks or needs that may give rise to social protection are: Sickness/Health care, disability, old age, survivors, family/children, unemployment, housing, social exclusion not elsewhere classified.

Benefits granted within the framework of social protection can take many forms: Cash payments to protected people, reimbursements of expenditure made by protected people, goods and services directly provided to protected people. The expenditure defined in transaction categories of social protection schemes are: Social benefits, administration costs, transfers to other schemes, other expenditure

We focus on three types the social benefits classified by eight functions according to defined risks or needs that may give rise to social protection:

1. Old age: Income maintenance and support in cash or kind (except health care) in connection with old age. 
2. Family/children: Support in cash or kind (except health care) in connection with the costs of pregnancy, childbirth and adoption, bringing up children and caring for other family members.

3. Unemployment: Income maintenance and support in cash or kind in connection with unemployment.

\section{Research methodology}

The existence of trade off efficiency and equity problem projected into the social protection and socio-economic development is what is being statistically tested through the correlation analysis of social protection expenditure and human development index.

The object of quantitative analysis, the selected sample, comprises the following countries: Slovakia, Czech Republic, Hungary, Poland, Great Britain, Sweden, France, Germany, Thailand, Austria, USA, Canada, Australia, Japan and Mexico. The sample was deliberately selected in order to ensure its heterogeneity from the viewpoint of observed indicators/variables influencing the statistical testing. With regard to availability, the indicators pertain to the periods of: 2009-2005, 2000, 1995 and 1990.

Key methods of scientific research are those based on classification analysis, comparison and abstraction in creation of the theoretical-methodological frame for the solution; methods of causal analysis and comparison when solving the defined research question in the application part, and methods of synthesis and partial induction when concluding the outcomes. The complexity in the space of global economy entails a high degree of abstraction in research of secondary character. Secondary collecting of data from OECD statistics available was carried out through the constructive method, and its processing and interpretation through statistical methods with the emphasis placed on correlation analysis.

The Pearson correlation coefficient determines the strength of the dependence among between observed variables. It shows the level of closeness of linear dependence. The estimate of a pair correlation coefficient is defined as the estimate of covariance $\mathrm{x}$ and $\mathrm{y}$ divided by the multiplication of estimates of their standard deviations, i.e.

$$
r_{y x}=\frac{\operatorname{cov}_{x y}}{s_{x} s_{y}}
$$

where $\operatorname{cov}_{\mathrm{xy}}$ is the covariance between $\mathrm{x}$ and $\mathrm{y}$ a can be calculated as the average of multiplication of deviations, i.e. it is a "common" measure of variability (covariance) for two features ( $\mathrm{x}$ and $\mathrm{y}$ ).

The equation is based upon covariance, which is the level of mixed variability of variables $\mathrm{x}$ and $\mathrm{y}$ :

$$
\operatorname{cov} x y=\frac{1}{n} \sum_{i=1}^{n}(x \mathrm{i}-\bar{x})(y \mathrm{i}-\bar{y})=\overline{x y}-\bar{x} \cdot \bar{y}
$$

The coefficient of pair correlation (Pearson's correlation coefficient) has the values ranging from $\langle-1,+1\rangle$, while the more the value approaches -1 , the closer the correlation is (direct linear correlation in case of positive values, indirect in case of negative 
ones); the more it approaches zero, the weaker the correlation is. On both sides, correlation coefficients provide dependence between $\mathrm{x}$ and $\mathrm{y}$ (Hendl 2012; Wonnacott, Wonnacott 1991).

The value of correlation coefficient identifies the presence of dependence relation between the level of economic development and the extent of social protection and its intensity in accordance with the following scale:
Weak correlation $<0 ; 0.3>$

Moderate correlation $<0.3 ; 0.7>$
Strong correlation $<0.7 ; 1>$

The calculations in the following part are the output of the SPSS Statistics 18.0 software.

\section{Results and Discussion}

According to ESSPROS Manual and user guidelines (2012), expenditures on social protection are divided into four categories. The first are expenditures on social benefits, which are resources in the form of cash, products or services. The second category relates to administrative expenses, connected with the system of providing social protection. The third and fourth category deals with transfers into other systems and various expenditures.

Table 1 Social Protection Expenditure in the Area of Family Policy [\%]

\begin{tabular}{lcccccccc}
\hline & 1990 & 1995 & 2000 & 2005 & 2006 & 2007 & 2008 & 2009 \\
\hline Australia & 1.5 & 2.7 & 2.9 & 2.7 & 2.6 & 2.5 & 3.3 & 2.8 \\
Austria & 2.6 & 3.1 & 2.8 & 2.8 & 2.7 & 2.6 & 2.7 & 2.9 \\
Canada & 0.6 & 0.8 & 1.0 & 1.1 & 1.0 & 1.1 & 1.0 & 1.1 \\
Czech Republic & 2.4 & 1.9 & 1.9 & 1.7 & 1.6 & 1.9 & 1.7 & 1.8 \\
France & 2.5 & 2.7 & 3.0 & 3.0 & 3.0 & 3.0 & 3.0 & 3.2 \\
Germany & 1.6 & 2.1 & 2.1 & 2.1 & 1.8 & 1.8 & 1.9 & 2.1 \\
Hungary &.. &.. & 3.1 & 3.1 & 3.4 & 3.4 & 3.4 & 3.6 \\
Italy & 0.8 & 0.6 & 1.1 & 1.3 & 1.4 & 1.4 & 1.4 & 1.6 \\
Japan & 0.4 & 0.5 & 0.6 & 0.8 & 0.8 & 0.8 & 0.9 & 1.0 \\
Mexico & 0 & 0,1 & 0,7 & 1.0 & 1.0 & 1.0 & 1.1 & 1.1 \\
Poland & 1.7 & 1,1 & 1,2 & 1.1 & 1.1 & 1.1 & 1.1 & 1.1 \\
Slovak Republic &.. & 2,5 & 2.0 & 1.9 & 1.9 & 1.8 & 1.7 & 2.0 \\
Sweden & 4.4 & 3.8 & 3.0 & 3.3 & 3.4 & 3.4 & 3.5 & 3.7 \\
United Kingdom & 1.9 & 2.3 & 2.7 & 3.2 & 3.1 & 3.3 & 3.5 & 3.8 \\
USA & 0.5 & 0.6 & 0.7 & 0.7 & 0.7 & 0.7 & 0.7 & 0.7 \\
\hline Source: Own processing & according & to OECD. & & & & &
\end{tabular}


This study focuses on three types of social protection expenditures - in the area of family policy, on unemployment and old age, in selected countries and periods of time. The following tables provide their level.

The ratio of social protection expenditures in family policy as \% of the GDP according to OECD statistical data in selected countries is shown in Table 1.

In the observed period, the lowest share of social protection expenditures on family policy (Table 1) was provided in the USA, Japan, Mexico and Canada. By contrast, the largest share of expenditures on family policy was found in the case of Sweden and Hungary, which are countries with the most generous system of social policy and a high level of redistribution. Since 2005, also the United Kingdom of Great Britain and Northern Ireland was achieving the biggest share of expenditures on family policy. Social protection expenditures on passive employment policy (unemployment compensation /severance pay) differ among countries (according to the duration of its providing and to $\%$ from the previous income) according to the concept of the adopted employment policy. Their level as the \% of GDP, based on OECD data in selected countries, is shown in Table 2.

Table 2 Social Protection Expenditure in the Area of Employment Policy [\%]

\begin{tabular}{lcccccccc}
\hline & 1990 & 1995 & 2000 & 2005 & 2006 & 2007 & 2008 & 2009 \\
\hline Australia & 1.1 & 1.2 & 0.9 & 0.5 & 0.5 & 0.4 & 0.4 & 0.5 \\
Austria & 0.9 & 1.3 & 0.9 & 1.1 & 1.0 & 0.9 & 0.9 & 1.1 \\
Canada & 1.9 & 1.3 & 0.7 & 0.6 & 0.6 & 0.6 & 0.7 & 1.0 \\
Czech Republic &.. & 0.4 & 0.6 & 0.6 & 0.5 & 0.6 & 0.6 & 1.0 \\
France & 1.7 & 1.6 & 1.5 & 1.7 & 1.5 & 1.4 & 1.3 & 1.5 \\
Germany & 0.8 & 1.5 & 1.3 & 1.9 & 1.7 & 1.4 & 1.3 & 1.7 \\
Hungary &.. & 0.9 & 0.7 & 0.6 & 0.6 & 0.7 & 0.7 & 0.9 \\
Italy & 0.6 & 0.7 & 0.4 & 0.5 & 0.5 & 0.4 & 0.5 & 0.8 \\
Japan & 0.3 & 0.5 & 0.6 & 0.3 & 0.3 & 0.3 & 0.4 & 0.7 \\
Mexico & - & - & - & - & - & - & - & - \\
Poland & 0.0 & 1.6 & 0.9 & 0.5 & 0.5 & 0.3 & 0.2 & 0.3 \\
Slovak Republic &.. & 0.4 & 0.6 & 0.3 & 0.3 & 0.4 & 0.4 & 0.7 \\
Sweden & 0.9 & 2.3 & 1.4 & 1.2 & 1.0 & 0.7 & 0.5 & 0.7 \\
United Kingdom & 0.7 & 0.9 & 0.3 & 0.3 & 0.2 & 0.2 & 0.3 & 0.5 \\
USA & 0.4 & 0.3 & 0.2 & 0.3 & 0.3 & 0.3 & 0.3 & 0.9 \\
\hline
\end{tabular}

Note: The social protection expenditure in the area of employment policy in Mexico was not available in the monitored years.

Source: Own processing according to OECD.

Over the observed period, the share of social protection expenditures in the area of employment policy as a GDP share ranged from $0.2-1.9 \%$ in the selected countries (see Table 2). A slightly increasing tendency of the shares of expenditures in the area of employment policy was observed mainly in Japan and the USA, from European coun- 
tries in Germany, the Czech Republic, Italy and Slovakia. By contrast, a slightly decreasing share of expenditures in the area of employment policy was observed in Australia, in Europe in France, Poland, Sweden or the United Kingdom. The highest share of expenditures on employment policy was observed in France and Germany in 2009, by contrast the lowest share was in Poland. The share of expenditures on social protection, which individual countries allocate for the area of employment policy as a GDP share, is relatively small in comparison with the share of expenditures on old age. Expenditure on social protection on old age as the \% of GDP, based on OECD data in selected countries, is shown in Table 3.

Table 3 Social Protection Expenditure on Old Age [\%]

\begin{tabular}{lcccccccc}
\hline & 1990 & 1995 & 2000 & 2005 & 2006 & 2007 & 2008 & 2009 \\
\hline Australia & 3.3 & 3.9 & 4.7 & 4.3 & 4.7 & 4.7 & 4.9 & 4.9 \\
Austria & 8.9 & 10.0 & 10.4 & 10.8 & 10.7 & 10.7 & 11.0 & 12.0 \\
Canada & 3.8 & 4.2 & 3.9 & 3.7 & 3.7 & 3.7 & 3.8 & 4.1 \\
Czech Republic & 5.0 & 5.6 & 6.8 & 6.6 & 6.5 & 6.6 & 7.0 & 7.8 \\
France & 9.2 & 10.6 & 10.5 & 10.9 & 11.0 & 11.1 & 11.5 & 12.3 \\
Germany & 9.4 & 7.8 & 8.6 & 9.1 & 8.8 & 8.5 & 8.5 & 9.1 \\
Hungary &.. &.. & 7.0 & 7.8 & 8.0 & 8.4 & 8.8 & 9.1 \\
Italy & 8.2 & 9.3 & 11.1 & 11.5 & 11.6 & 11.7 & 12.2 & 13.0 \\
Japan & 4.0 & 5.2 & 6.8 & 8.6 & 8.7 & 8.8 & 9.3 & 10.4 \\
Mexico & 0.4 & 0.6 & 0.6 & 0.9 & 1.0 & 1.1 & 1.2 & 1.4 \\
Poland & 4.1 & 7.6 & 8.5 & 9.3 & 9.4 & 8.7 & 8.9 & 9.8 \\
Slovak Republic &.. & 5.5 & 5.7 & 5.7 & 5.6 & 5.4 & 5.2 & 6.4 \\
Sweden & 8.6 & 9.8 & 9.1 & 9.4 & 9.1 & 9.0 & 9.4 & 10.2 \\
United Kingdom & 4.8 & 5.5 & 5.5 & 5.9 & 5.7 & 5.7 & 6.2 & 6.7 \\
USA & 5.2 & 5.4 & 5.1 & 5.3 & 5.2 & 5.3 & 5.5 & 6.1 \\
\hline Source: own processing according to OECD. & & & & & &
\end{tabular}

Source: own processing according to OECD.

Over the years 1990-2009, the social protection expenditure share in the area of pensions in all selected countries demonstrated a slightly increasing tendency, with the exception of Germany where a slight decrease took place. In 2009, France, Austria, Sweden and Japan had largest expenditures in the area of pension policy. Over the years 1990-2009, the most notable increase in expenditures in the area of pension policy was observed mainly in Japan, by $6.4 \%$, in Europe in Poland, Italy, Austria and France, by $5.7 \%, 4.8 \%, 3.1 \%$ and $3.1 \%$, respectively. It may be assumed that this pertains mainly to legislature and implemented instruments of social policy, in connection with aging of population, and also traditions and customs in the respective countries. However, a very low share of social security in the area of pensions was observed in non-European countries over the defined period. The lowest share of expenditures on old age was observed in Mexico (around 1\%), Australia and Canada (between 3-4\%). 
In theory, the amount of the social protection expenditures should be reflected on the achieved level of economic development quantified by the HDI (Table 4).

Table 4 Level of Economic Development Quantified by the HDI

\begin{tabular}{lcccccccc}
\hline & 1990 & 1995 & 2000 & 2005 & 2006 & 2007 & 2008 & 2009 \\
\hline Australia & 0.873 & 0.889 & 0.906 & 0.918 & 0.920 & 0.922 & 0.924 & 0.926 \\
Austria & 0.790 & 0.814 & 0.839 & 0.860 & 0.866 & 0.870 & 0.876 & 0.879 \\
Canada & 0.857 & 0.870 & 0.879 & 0.892 & 0.897 & 0.900 & 0.903 & 0.903 \\
Czech Republic & - & 0.788 & 0.816 & 0.854 & 0.858 & 0.861 & 0.864 & 0.863 \\
France & 0.777 & 0.819 & 0.846 & 0.869 & 0.873 & 0.877 & 0.879 & 0.880 \\
Germany & 0.795 & 0.835 & 0.864 & 0.895 & 0.898 & 0.901 & 0.902 & 0.900 \\
Hungary & 0.706 & 0.737 & 0.775 & 0.803 & 0.808 & 0.809 & 0.811 & 0.811 \\
Italy & 0.764 & 0.795 & 0.825 & 0.861 & 0.866 & 0.869 & 0.871 & 0.870 \\
Japan & 0.827 & 0.850 & 0.868 & 0.886 & 0.891 & 0.894 & 0.896 & 0.895 \\
Mexico & 0.649 & 0.674 & 0.718 & 0.741 & 0.748 & 0.755 & 0.761 & 0.762 \\
Poland & - & 0.727 & 0.770 & 0.791 & 0.795 & 0.800 & 0.804 & 0.807 \\
Slovak Republic & 0.747 & 0.752 & 0.779 & 0.810 & 0.817 & 0.825 & 0.831 & 0.829 \\
Sweden & 0.816 & 0.855 & 0.894 & 0.896 & 0.898 & 0.899 & 0.900 & 0.898 \\
United Kingdom & 0.778 & 0.816 & 0.833 & 0.855 & 0.853 & 0.856 & 0.860 & 0.860 \\
USA & 0.870 & 0.883 & 0.897 & 0.902 & 0.904 & 0.905 & 0.907 & 0.906 \\
\hline Source: own processing according to Human Development Report & & &
\end{tabular}

The relation between the extent of selected types of social protection expenditures and the level of economic development achieved is arrived at through the Pearson correlation coefficient (Table 5).

Table 5 Correlation of Observed Types of Social Protection Expenditure and the HDI in Time - Selected Countries

\begin{tabular}{lcccccccc}
\hline The sphere of social policy & 1990 & 1995 & 2000 & 2005 & 2006 & 2007 & 2008 & 2009 \\
\hline Family policy & 0.13 & 0.27 & 0.16 & 0.16 & 0.09 & 0.08 & 0.14 & 0.09 \\
Employment policy & 0.07 & 0.11 & 0.16 & 0.25 & 0.25 & 0.19 & 0.21 & 0.29 \\
Policy of old-age pensions & 0.15 & 0.22 & 0.22 & 0.25 & 0.25 & 0.25 & 0.25 & 0.24 \\
\hline Source: own processing & & & & & & & &
\end{tabular}

Over the years 1990-2009, the Pearson correlation coefficient demonstrates weak linear dependence between social protection expenditures and the achieved level of economic development in the case of:

- the extent of social protection expenditures on family and the HDI in 1995, 
- the extent of social protection expenditures on unemployment and the HDI in 2005, 2006 and 2009,

- $\quad$ social protection expenditures on old age and the HDI over 2005-2009.

On the basis of the Pearson correlation coefficient, a weak link between the extent of social protection expenditures in the area of family policy and the HDI in 1995, and as the determination coefficient demonstrates, too, there is $7.3 \%$ mutual influence, and $92.7 \%$ influence by other factors.

It is also possible to notice a week correlation between the extent of social protection expenditures in the area of employment policy and the HDI in 2005 and 2006, when the determination coefficient equals $6.25 \%$. These indicators show a $6.25 \%$ mutual influence, and $93.75 \%$ influence by other factors. In 2009 as well, a weak correlation between these indicators was proven according to the Pearson correlation coefficient of 0.29 with the determination coefficient of $8.4 \%$.

Table 6 Pearson's Correlation Coefficient of Observed Types of Social Protection Expenditures and HDI Index for Individual Countries

\begin{tabular}{lccc}
\hline & Family policy & Employment policy & Old-age pension policy \\
\hline Australia & 0.72 & -0.93 & 0.93 \\
Austria & -0.11 & -0.13 & 0.91 \\
Canada & 0.90 & -0.81 & -0.26 \\
Czech Republic & -0.58 & 0.53 & 0.69 \\
France & 0.94 & -0.64 & 0.88 \\
Germany & 0.34 & 0.72 & -0.06 \\
Hungary & 0.72 & -0.48 & 0.87 \\
Italy & 0.92 & -0.22 & 0.95 \\
Japan & 0.95 & 0.08 & 0.97 \\
Mexico & 0.99 & - & 0.91 \\
Poland & -0.23 & -0.99 & 0.86 \\
Slovak Republic & -0.87 & -0.01 & 0.11 \\
Sweden & $-0,86$ & -0.33 & 0.37 \\
United Kingdom & 0.95 & -0.71 & 0.84 \\
USA & 0.97 & 0.14 & 0.34 \\
\hline Source: own processing & & &
\end{tabular}

The correlation relation between the social protection expenditures on old age and the HDI over the years 2005-2009 proved a weak correlation. The determination coefficient shows that over the years 2005-2008, there was $6.25 \%$ mutual influence, and $93.75 \%$ influence by other factors. An even weaker link was proved in the year 2009, when there was just $5.3 \%$ mutual influence between these indicators. 
Based on the Pearson correlation coefficient, also mutual relations between selected types of social protection expenditures (in the area of family policy, on unemployment and old age) and the achieved level of economic development - the HDI - were analyzed (see Table 6).

Over the years 1990-2009, based on the Pearson correlation coefficient, a strong linear dependence was proven in the extent of social protection expenditures on family policy, and the HDI in Australia, Canada, Japan, the USA and Mexico. France, Hungary, Italy and the UK were the European countries to prove a strong linear dependence of the extent of social protection expenditures in the area of family policy and the HDI. The higher social-security expenditures in the area of family policy are, the higher the HDI in these countries is.

A strong indirect linear dependence between the extent of social protection expenditures in the area of family policy and the HDI can be spotted in Sweden and Slovakia. It thus applies that the higher the social protection expenditures on family policy in these countries are, the lower the HDI over the observed years. By contrast, from the European countries, mainly Austria and Poland showed a weak indirect linear dependence between the extent of social protection expenditures on family policy and the HDI.

In European countries, a strong direct linear dependence of the extent of social protection expenditures on unemployment and the HDI can be traced in Germany, and a strong indirect linear dependence in Poland and the United Kingdom. In non-European countries, a strong indirect linear dependence of these indicators was observed in Australia and Canada. By contrast, in Austria, Italy, the USA or Japan, the dependence between the extent of social protection expenditures on family policy and the HDI is very weak.

The mutual relation between the extent of social protection expenditures on old age and the HDI over the observed period proves a strong direct linear dependence in majority of countries. However, Canada, Germany and Slovakia are exceptions, where a low linear dependence between social protection expenditures on old age and the HDI was proven. On the other hand, a moderate direct linear dependence was proven between the indicators in Sweden and the USA.

\section{Conclusions}

The question of trade off compromise between efficiency and equality is being increasingly discussed in not only economic and social, but also political terms. The general theoretical view on the solution of this issue is presented by the neoclassical school of welfare economics view of income redistribution. However, there are numerous methodological problems (definition of the function of social welfare, interpersonal comparison of individual well-being) that hamper the attempts to find a proper response. The balance between efficiency and equality also permeates into the execution of social policy and results of socio-economic policy achieved, with the aim to define an optimal extent and character of the processes of redistribution. That is achievable by defining those areas of social protection where public expenditures make a positive influence on the quality of life in a society (we can call it "productive social protection expenditure). The study tries to identify such kind of social protection expenditure by quantitative 
analysis of relation between the different types of social protection expenditure (on family, old age and unemployment) and socio-economic development measured by human development index. The relation is statistically tested on the sample of 15 countries, differing in the achieved level of socio-economic development and the extent and character of income redistribution processes. In most selected countries, expenditures on social protection in the area of family policy and on old age have a positive impact on the level of socio-economic development; by contrast, however, expenditures on unemployment have a rather negative impact. The outcomes of the research should be analyzed more deeply through the redistribution theory of defined compromise "trade off" between efficiency and equity. The compromise in each country depends on the character of the subparts and the models of social policy. Different models of family policy (liberal, social-market, universalistic), labor market policy (Scandinavian model, liberal model, consensual corporate democracy model) and concepts of pension policy (presented by liberal, socio-democratic and conservative model of social policy) cause markedly different extent and nature of redistribution processes.

\section{References}

APGAR, W. C., BROWN, H. J. (1987). Microeconomics and Public Policy. London: Scott, Foresman and Company.

BAILEY, S. J. (1995). Public Sector Economics. London: Macmillan.

BALDOCK, J. MITTON, L., MANNING, N., VICKERSTAFF, S. (2012). Social Policy. Oxford: University Press.

BARANOVÁ, V. (2013). The Impact of Price-Cost Competitiveness Factors on Economic Growth. Review of Economic Perspectives. 13(2), pp. 63-76. DOI: 10.2478/revecp-2013-0001

BENTHAM, J. (1781). „Introduction to the Principles of Morals and Legislation“. Batoche Books, Kitchener (2000). Retrieved August 28, 2013, from http://socserv.mcmaster.ca/econ/ugcm/31l3/bentham/morals.pdf.

BROWN, C. V., JACKSON, P. M. (1990). Public Sector Economics. Oxford: Blackwell Publishing.

COSTANTINI, V., MONNI, S. (2008). Environment, human development and economic growth. Ecological Economics. 4(64), pp. 867-880.

CULLIS, J., JONES, P. (1992). Public Finance and Public Choice. London: McGraw Hill Book Company.

CULliS, J., JONES, P. (1987). Public Sector Economics. Oxford: Blackwell Publishing.

DINIZ, F., SEQUEIRA, T. (2012). A Social and Economic Development Index. NUTS Ranking in Portugal. American Journal of Economics. 2(7), pp. 146-163. DOI: 10.5923/j.economics.20120207.01 
Esspros. The European System of integrated Social PROtection Statistics. (2012). ESSPROS Manual and user guidelines. Luxembourg: Publications Office of the European Union (ISBN 978-92-79-24751-4). DOI: 10.2785/29417

Esspros. The European System of integrated Social PROtection Statistics (2011). ESSPROS Manual. Luxembourg: Publications Office of the European Union (ISBN 978-9279-20904-8). DOI: $10.2785 / 16441$

FARNSWORTH, K., IRVING, Z. (2011). Social policy in challenging times. Economic crisis and welfare systems. Bristol: Policy Press University of Bristol.

HALÁSKOVÁ, M., HALÁSKOVÁ, R. (2013). Interrelations of Public Expenditures on Public Services in EU Countries. In Finance and the Performance of Firms in Science, Education and Practice. Zlín: Univerzita Tomáše Bati. ISBN 978-80-7454-246-6 pp. 255-269.

HAYEK, F. A. (1994). Právo, zákonodárství a svoboda. Nový výklad liberálních principů spravedlnosti a politické ekonomie. Praha: Akademie věd ČR.

HENDL, J. (2012). Přehled statistických metod: analýza a metaanalýza dat. Praha: Portál.

HRONEC, Š., ŠTRANGFELDOVÁ, J. (2013). Socio-Economic Effects of Education in the Contex of Economic Return. The New Educational Review. 32 (2), pp. 172-183.

Human Development Report (2013). Human Development Report 2013. New York: United Nations Development Programme (ISBN 978-92-1-126340-4). Retrieved from http://hdr.undp.org/en/media/HDR_2013_EN_complete.pdf

IMMERVOLL, H., RICHARDSON. L. (2011). "Redistribution Policy and Inequality Reduction in OECD Countries: What Has Changed in Two Decades?", OECD Social, Employment and Migration Working Papers, No. 122, OECD Publishing. Retrieved January 25, 2014, from http://dx.doi.org/10.1787/5kg5dlkhjq0x-en

LASKI, K, RÖMISCH, R. (2003, Jul). From Accession to Cohesion: Ireland, Greece, Portugal and Spain and Lessons for the Next Accesstion. WIIW Research Reports. Retrieved December 29, 2012, from http://ideas.repe c.org/p/wii/rpaper/rr298.html

MANKIW, G. N. (2010). Macroeconomics. Worth Publishers.

MEHROTRA, A. N., PELTONEN, T. A. (2005). Socio-economic development and fiscal policy. European Central Bank. Retrieved January 10, 2013, from http://www.ecb.int/pub/pdf/scpwps/ecbwp467.pdf

MUSGRAVE, R.A. (1959). The Theory of Public Finance. London: McGraw - Hill.

NEMEC, J., OCHRANA, F., ŠUMPÍKOVÁ, M. (2008). Czech and Slovak lessons for public administration performance evaluation, management and finance. Ekonomický časopis. 56(4), pp. $353-369$.

OECD.(2013). OECD.StatExtracts. Retrieved January 28, 2013, from http://stats.oecd.org/Index.aspx?DataSetCode=SOCX_AGG.

OCHRANA, F., NEKOLA, M. (2009). Economic evaluation of public programs. Ekonomický časopis. 57(5), pp. 458 - 74. 
OTÁHAL, T., PALÁT, M., WAWROSZ, P. (2013). What is the Contribution of the Theory of Redistribution Systems to the Theory of Corruption? Review of Economic Perspectives. 13(2), pp. 92-107. DOI: 10.2478/revecp-2013-0003

PESTIEAU, P. (2006). The Welfare State in the European Union: Economic and social Perspectives. Oxford: Oxford University Press.

RANIS, G. (2004). Human Development and Economic Growth. Yale University Economic Growth Center Discussion Paper, No. 887. Retrieved March 6, 2014, from http: //papers.ssrn. com/sol3/ papers.cfm? abstract_id=551662.

SAUNDERS, P. (1993). Recent trends in the Size and Growth of Government in OECD Countries. In Gemmel, N., The growth of the Public Sector. London: Macmillan \& Co Ltd.

SINGER, N.M. (1972). Public Microeconomics. Boston: Little, Brown and Company.

STIGLITZ, J. E. (1988). Economics of the Public sector. London: Norton \& Company New York.

WONNACOTT T., WONNACOTT R. (1991). Statistika pro obchod a hospodářství. Praha: Victoria Publishing. 